\title{
Pemberdayaan Masyarakat Tergusur Akibat Pembangunan Bendungan Nipah-Sampang Madura Melalui Pengembangan Kawasan Desa Wisata Syariah
}

\author{
Andrie Kisroh Sunyigono, Rosyida Ekawati, Mardiyah Hayati \\ Program Studi Agribisnis Fakultas Pertanian \\ Universitas Trunojoyo Madura \\ E-mail : sunyigono@gmail.com \\ http://dx.doi.org/10.21107/pgd.v4i2.4940
}

\begin{abstract}
Abstrak
Kabupaten Sampang adalah salah satu kabupaten yang ditempati Kuliah Kerja Nyata Universitas Trunojoyo Madura Semester. Hal ini didasarkan pada pertimbangan masih rendahnya Indeks Pembangunan Manusia (IPM) Kabupaten Sampang sebesar 59.58. Penerjunan mahasiswa KKN di Kabupaten Sampang diharapkan dapat memberikan dampak positif bagi pemberdayaan masyarakat. Target luaran dalam program kegiatan ini adalah: a) Kelancaran proses transfer ilmu pengetahuan teknologi dan seni dari perguruan tinggi ke masyarakat dalam upaya pemecahan masalah yang dihadapi masyarakat, b) Peningkatan kepekaaan mahasiswa dalam mensikapi permasalahan yang terjadi di masyarakat, c) Peningkatan keterampilan masyarakat di sekitar Bendungan Nipah dengan kegiatan produktif seperti kerajinan bambu dan pangan, d) Terbukanya peluang usaha baru dibidang wisata syariah yaitu souvenir bercirikan Kemaduraan dan Keislaman, e) Perbaikan sistem kerja kelompok usaha mitra melalui penerapan system pembukuan sederhana. Hasil dari kegiatan KKN-PPM ini adalah: 1. Terbentuknya dua kelompok usaha kerajinan bambu di Desa Nagasareh dan Desa Pelanggaran Barat sebagai kelanjutan dari Kelompok Posdaya yang telah dibentuk pada KKN periode sebelumnya, 2. Kedua kelompok usaha tersebut telah mampu membuat 10 varian produk kerajinan bambu sebagai hasil pelatihan, 3. Kemampuan masyarakat dalam manajemen usaha dan pembukaan sederhana meningkat.
\end{abstract}

Kata Kunci : pemberdayaan masyarakat, Sampang, kuliah kerja nyata, kerajinan

\section{PENDAHULUAN}

Salah satu lokasi kegiatan Kuliah Kerja Nyata (KKN) Universitas Trunojoyo Madura adalah Kabupaten Sampang. Pemilihan daerah didasari oleh pertimbangan masih rendahnya indeks pembangunan manusia di kabupaten tersebut. Sebagai perbandingan Indeks Pembangunan Manusia (IPM) Jawa Timur pada tahun 2010 adalah 71.55 (BKKBN Jawa Timur, 2012) sedangkan IPM Kabupaten Sampang adalah 59.58. Bahkan IPM kabupaten ini juga terendah di Pulau Madura (IPM Sumenep 65.3, Bangkalan 64.52 dan Pamekasan 64.41) dan Sampang 59.58. Dari data diatas Nampak bahwa Kabupaten Sampang mempunyai IPM terendah di Jawa Timur dan di Madura. Ditinjau dari aspek pendidikan, IPM yang rendah berkorelasi positif dengan rendahnya beberapa indikator pendidikan. Tingkat pendidikan di Sampang sangat rendah. Bahkan penduduk Kabupaten Sampang rata-rata mengenyam pendidikan hanya sampai pada tingkat 3 sekolah dasar. Kondisi ini terendah di Indonesia. Demikian juga dengan penduduk buta huruf di Sampang masih sangat tinggi yaitu adalah terendah di Jawa Timur yaitu 142 ribu orang atau $34.96 \%$ dari total penduduk. Selanjutnya jumlah penduduk yang putus sekolah dan anak yang berada pada usia sekolah dan tidak melanjutkan ke jenjang selanjutnya masih sangat tinggi.

Apabila dilihat dari aspek IPM yang lain yaitu indikator ekonomi, pada tahun 2010 tingkat pertumbuhan ekonomi Kabupaten Sampang terendah di Jawa Timur yaitu 5.33\%. Saat ini pertumbuhan ekonomi Kabupaten Sampang masih terendah dibandingkan tiga kabupaten lain di Pulau Madura. Potensi ekonomi masih belum dioptimalkan seperti potensi pertanian di daerah utara serta pemanfaatan infrastruktur yang belum dimaksimalkan.

Hal senada juga bisa dilihat pada indikator IPM berikutnya yaitu Indikator kesehatan. Tingkat capaiannya juga masih rendah. Salah satu indikatornya adalah tingginya angka kematian bayi yaitu 58.92 per 1000 kelahiran hidup. Perlu upaya penyadaran masyarakat akan pentingnya arti kesehatan dan pemerintah harus mendorong dan memfasilitasi masyarakat agar 
mau dan mampu untuk merubah pola hidupnya menjadi pola hidup yang lebih sehat.

Namun demikian, Kabupaten Sampang mempunyai potensi untuk dikembangkan yang diharapkan mampu meningkatkan taraf hidup masyarakat. Salah satu potensi yang belum digarap dengan serius adalah bidang pertanian. Pemerintah Kabupaten Sampang telah menetapkan Kecamatan Banyuates sebagai sentra agrobisnis di Kabupaten Sampang. Hal ini didasari oleh beberapa pertimbangan adanya beberapa potensi yaitu potensi masyarakat, potensi lahan dan potensi vegetasi. Potensi masyarakat di kawasan tersebut (termasuk Desa Nagasareh, Pelanggaran Barat dan Masaran) sangat mendukung untuk dikembangkan sebagai kawasan agribisnis. Kultur agraris masyarakat yang kuat serta pengalaman berusahatani yang panjang merupakan peluang besar yang sangat dibutuhkan dalam mengembangkan kawasan agribisnis. Mereka sudah mempunyai pengalaman yang luar biasa dalam bercocok tanam. Hanya perlu didorong untuk mampu menerapkan teknologi produksi baru agar produktifitas hasil usahataninya meningkat.

Kecamatan Banyuates mempunyai luas lahan pertanian yang paling luas dibandingkan Kecamatan Sokobanah dan Kecamatan Ketapang yang sama-sama akan dikembangkan sebagai kawasan agribisnis di Kabupaten Sampang. Luas lahan pertanian sawah di Kecamatan Banyuatas adalah 1.076 Ha sedangkan non sawah 12.083 Ha sedangkan untuk lahan non pertanian hanya 964 Ha. Sehingga penggunaan lahan untuk aktifitas pertanian lebih besar hingga mencapai 91.93 Ha dari luas lahan secara keseluruhan, atau bisa dikatakan $93 \%$ dari luas lahan digunakan untuk aktifitas pertanian dan sisanya $7 \%$ untuk non pertanian.

Potensi vegetasi di Desa Nagasareh, Pelanggaran Barat dan Nagasareh sangat beragam. Umumnya adalah tanaman semusim (pangan, buah-buahan dan industri) serta tanaman tahunan. Jenis tanaman semusim diantaranya adalah padi, jagung, ketela, sorghum, bentul (pangan), semangka dan pisang (buahbuahan), cabe jamu, pandan, rumput gajah (industri). Sedangkan untuk tanaman tahunan diantaranya adalah mente, mangga, jati, nangka, bambu dan kelapa.

Untuk mendukung program tersebut, Pemerintah Kabupaten Sampang telah membangun Bendungan Nipah di Kecamatan Banyuates Kabupaten Sampang. Salah satu tujuannya adalah untuk meningkatkan ketersediaan air untuk irigasi sehingga jumlah lahan beririgasi teknis akan meningkat dari yang semula 225 hektar yang sudah mendapatkan sumber air dari Bendungan Montor dtambah dengan 925 ha yang merupakan areal sawah tadah hujan.

Pembangunan Bendungan Nipah merupakan solusi untuk pertumbuhan wilayah di kawasan di dataran rendah seperti Desa Montor, Tebanah dan desa-desa sekitarnya karena mampu memperluas lahan pertanian yang berigasi teknis seluas $225 \mathrm{Ha}$ (semula irigasi semi teknis) dan $925 \mathrm{Ha}$ (semula tanah tadah hujan). Sehingga ditinjau dari dampak positifnya memang cukup besar dalam rangka mengurangi keterbatasan air di Pulau Madura khususnya Kabupaten Sampang. Namun dampak negatifnya juga cukup besar. Pembebasan lahan untuk daerah tangkapan bendungan seluas 357,073 ha yang tersebar di 7 desa menimbulkan dampak sosial, ekonomi dan budaya yang besar. Pembebasan lahan yang dilakukan sejak 1981 telah memberikan ganti rugi kepada 1,871 kepala keluarga, namun hingga tahun 2013 proses pembebasan lahan masih belum selesai karena klaim masyarakat bahwa lahannya masuk ke dalam daerah tangkapan masih terus terjadi.

Meskipun bangunan bendungan sudah selesai namun proses penggenangan masih belum dilakukan, menunggu terselesaikannya proses pembebasan lahan. Permasalahan lainnya adalah sebagian besar masyarakat yang telah menjual lahannya hingga saat ini belum pindah dari daerah tangkapan sedangkan uang ganti rugi telah habis. Dari aspek sosial, permasalahan besar yang dihadapi oleh masyarakat di sekitar kawasan Bendungan Nipah adalah rendahnya tingkat pendidikan penduduk. Sebagian besar penduduk tidak tamat SD dan atau masih berpendidikan SD $(71.1 \%)$ sedangkan sisanya berpendidikan SMP. Jumlah penduduk yang lulus SLTA dan Sarjana masih sangat terbatas. Hal ini menyebabkan sebagian besar penduduk bermata pencaharian sebagai petani yang unskilled labour dan mereka kesulitan untuk beralih ke sektor lain. Sehingga potensi munculnya pengangguran baru sangat besar yang akan menimbulkan multiplier effect yang negative untuk daerah di sekitarnya. Permasalahan krusial lainnya adalah besarnya jumlah penduduk yang terdampak bendungan dan mereka masih berada pada kawasan tangkapan air. Jumlah mereka berkisar 9.355 jiwa. 


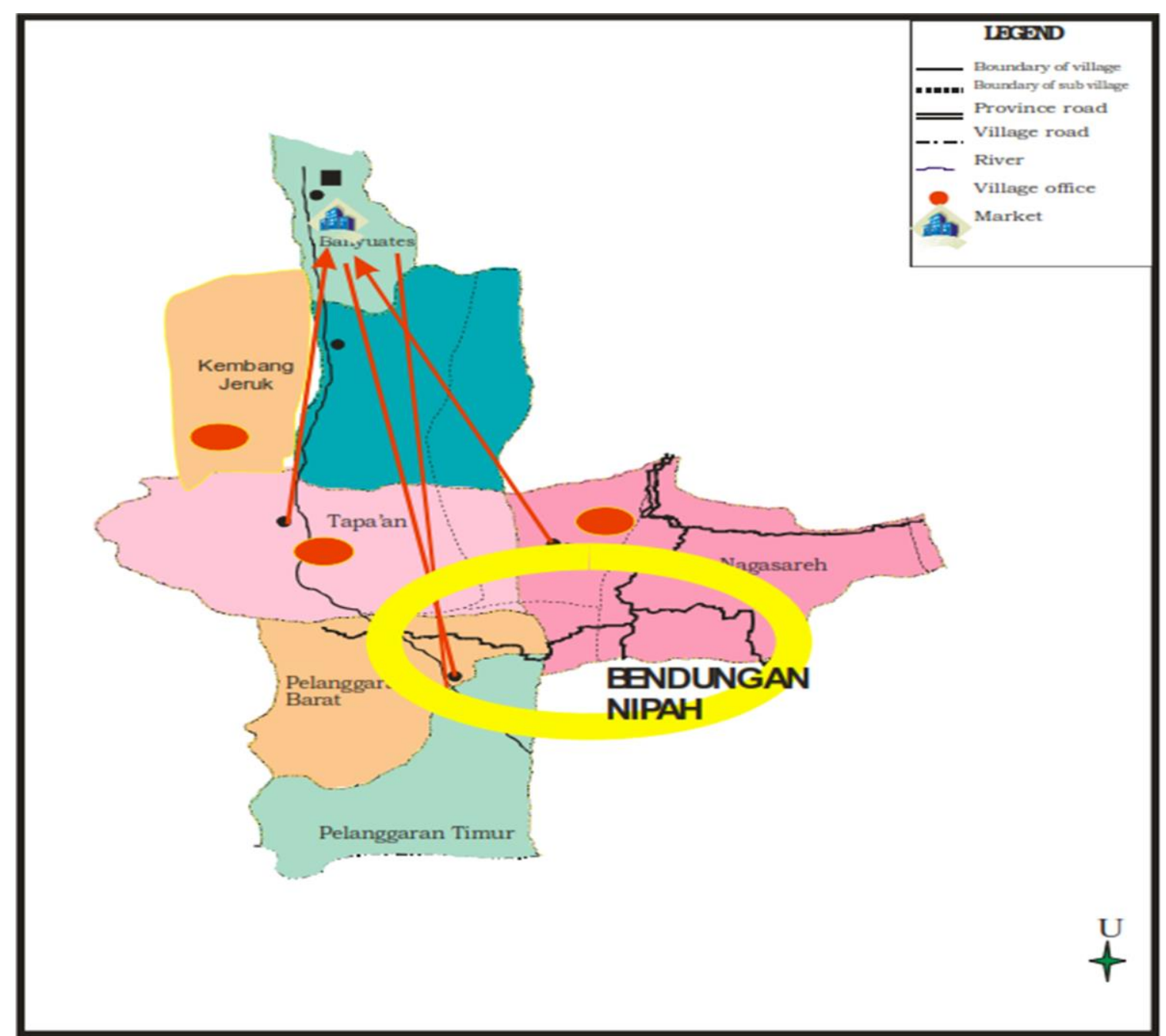

Gambar 1. Lokasi Bendungan Nipah Kabupaten Sampang

Dari uraian diatas maka rumusan masalah yang dihadapi oleh masyarakat di sekitar Bendungan (Nagasareh, Pelanggaran Barat dan Masaran) adalah :

1. Tingkat pendidikan dan keterampilan yang rendah.

2. Rendahnya lapangan pekerjaan khususnya di luar bidang pertanian.

3. Pendapatan penduduk yang rendah yang berimplikasi pada rendahnya tingkat kualitas hidup.

4. Kurangnya akses pemasaran.

5. Rendahnya manajemen usaha.

6. Keterbatasan modal kerja.

7. Rendahnya daya beli masyarakat.

8. Rendahnya kemampuan petani dalam melaksanakan proses produksi.

9. Sarana dan prasarana kurang memadai (seperti kerusakan jalan dan minimnya sarana air bersih)
Target dari kegiatan Kuliah Kerja Nyata Pembelajaran Pemberdayaan Masyarakat (KKNPPM) ini adalah :

1. Meningkatkan kepedulian, kepekaan dan daya nalar mahasiswa dalam menemu kenali permasalahan yang ada di dalam masyarakat serta mencari solusi pemecahannya berdasarkan pada bekal keilmuan yang telah mereka terima.

2. Memperkuat jalinan kemitraan antara Akademisi - Pemerintah - Masyarakat, dalam rangka meningkatkan kesejahteraan masyarakat melalui sinergi pemberdayaan masyarakat.

3. Meningkatkan keterampilan masyarakat di sekitar Bendungan Nipah dengan kegiatan produktif seperti kerajinan bambu dan logam.

4. Membuka peluang usaha baru diluar sektor pertanian bagi kelompok masyarakat yang kehilangan lahan akibat pembangunan Bendungan Nipah. 
5. Meningkatkan wawasan kelompok mitra dan masyarakat sekitar Bendungan tentang konsep Wisata Syariah.

6. Merevitalisasi peran dan kontribusi kelompok mitra dalam rangka meningkatkan kesejahteraan masyarakat.

\section{METODE}

Strategi yang dilakukan dalam pelaksanaan program KKN-PPM adalah bersifat partisipatif artinya semua metode dilakukan dengan memperhatikan dan melibatkan kelompok mitra. Adapun metode-metode tersebut adalah sebagai berikut :

1. Sosialisasi kegiatan : Metode sosialisasi dilakukan untuk memberikan informasi terkait dengan program KKN kepada dosen pembimbing lapang, mahasiswa KKN-PPM, kelompok mitra, masyarakat sekitar serta pemerintah lokal dan kabupaten.

2. Observasi dan identifikasi : Metode ini relevan untuk mengidentifikasi kondisi sasaran, masalah, potensi dan peluang pengembangan program. Metode ini juga digunakan untuk melakukan observasi program dan kegiatan yang tepat dan relevan dengan program dan kegiatan yang akan dilakukan.

3. Pelatihan : Metode pelatihan diberikan oleh expert baik yang berasal dari Universitas Trunojoyo Madura maupun praktisi/pakar dari luar universitas. Metode ini dimulai dengan proses identifikasi kondisi khalayak sasaran dan kondisi lingkungan yang berpengaruh sehingga materi yang diberikan akan sesuai dengan kondisi masyarakat.

4. Demoplot : Metode demoplot dilakukan setelah kegiatan pelatihan. Materi yang diperoleh dari pelatihan selanjutnya dipraktekkan agar peserta pelatihan lebih mempunyai kemampuan untuk mempraktekkan hasil yang bias dibuat.

5. Monitoring dan evaluasi : Monitoring dan evaluasi dilaksanakan mulai dari persiapan program kerja, pelaksanaan program kerja serta pasca pelaksanaan program KKN PPM.

Untuk menyelesaikan masalah sebagaimana disebutkan diatas maka langkah-langkah operasional yang dilakukan adalah:

- Persiapan dan sosialisasi serta pelatihan tim Pemberdayaan Masyarakat: Kegiatan ini dilakukan untuk mempersiapkan infrastruktur pendukung program KKN-PPM. Pada tahapan ini program KKN-PPM disosialisasikan kepada mahasiswa $\mathrm{KKN}$ -
PPM, dosen pembimbing lapang, kelompok mitra, masyarakat sekitar dan pemerintah. Disamping itu juga dibentuk dan dilatih kader/tim pemberdayaan yang nantinya menjadi agen perubahan yang mendampingi dan memfasilitasi kelompok mitra dengan arah dari LPPM UTM.

- Pelatihan penyusunan rencana kelompok Beberapa tahapan kegiatan yang dilakukan yaitu strategi pengembangan kelompok, pemantapan tupoksi kelompok, pembentukan AD/ART kelompok, serta penyusunan rencana kerja. Target dari kegiatan ini adalah anggota kelompok mampu menyusun rencana kerjanya sendiri dan mereka sudah mempunyai strategi pentahapan untuk melaksanakan rencana kerja tersebut.

- Pelatihan pengembangan kemampuan kerajinan masyarakat yaitu kerajinan bambu. Pelatihan kerajinan bambu didasarkan pada potensi yang ada pada masyarakat serta ketersedian sumber daya yang ada. Pada tahap awal akan pelatihan akan difasilitasi oleh expert baik dari dalam dan luar utm untuk memperkenalkan teknik-teknik pembuatan souvenir sederhana. Selanjutnya akan dikembangkan model-model souvenir yang lebih rumit dan tentunya bernilai ekonomis lebih mahal. Pada tahapan akhir akan dilakukan demonstrasi pembuatan kerajinan. Peserta didik juga diberi kesempatan untuk mempraktekkan hasil pelatihan yang telah diperoleh.

- Pelatihan manajemen wisata syariah : Pelatihan manajemen wisata syariah terdiri dari beberapa materi yaitu: Islam dan Pariwisata, Psikologi Pariwisata, serta Psikologi Islam. Selain itu, bahasa Arab Pariwisata, serta Pesantren dan Pariwisata.

- Pelatihan pemasaran dan pembukuan : Kegiatan ini ditujukan untuk memperkuat kemampuan kelompok mitra dalam manajemen usaha. Ada tiga kegiatan yang dilakukan yaitu pelatihantentang system akuntansi usaha kecil, pembukuan sederhana, serta aplikasi pembukuaan dengan komputer.

- Pendampingan dan Monev : Pertama kali kegiatan pendampingan dilakukan oleh tim mahasiswa KKN dan Dosen UTM. Selanjutnya kegiatan ini secara bertahap akan dilakukan oleh tim pemberdayaan masyarakat yang telah terbentuk. Sehingga kontinuitas program akan terjamin. Sedangkan pelaksanaan monitoring dan evaluasi $\mathrm{KKN}$ - 
PPM dilaksanakan sejak dari proses persiapan/penyusunan program, pelaksanaan, dan pasca pelaksanaan KKN-PPM.

\section{HASIL PEMBAHASAN}

Kegiatan pemberdayaan masyarakat sekitar Bendungan Nipah dengan pola Kuliah Kerja Nyata- Pembelajaran Pemberdayaan Masyarakat (KKN-PPM) dilaksasanakan secara bertahap mulai dari proses persiapan, pembekalan, pelaksanaan serta monitoring dan evaluasi. Adapun rincian kegiatan adalah sebagai berikut:

1. Persiapan KKN-PPM : Kegiatan persiapan dilakukan untuk mengkondisikan dan memobilisasi semua sumberdaya yang dimiliki dalam rangka pelaksanaan program pemberdayaan masyarakat. Secara garis besar kegiatan ini dapat dibagi menjadi beberapa kelompok aktifitas yaitu: a) persiapan dan mobilisasi mahasiswa, yang terdiri dari pendaftaran online dan verifikasi kelengkapan dokumen, b) persiapan internal (kesiapan panitia, dosen pembimbing lapangan, tim monitoring, kelengkapan buku panduan dan atribut KKN-PPM), c) koordinasi eksternal dengan muspika, pemerintah kabupaten, kecamatan dan desa (survey, observasi dan penentuan lokasi).

2. Pembekalan KKN-PPM : Kegiatan pembekalan wajib diikuti oleh semua mahasiswa KKN-PPM. Pembekalan dilakukan secara bergelombang sesuai dengan kelompoknya masing-masing. Adapun materi pembekalan yang diberikan: hakekat KKN, konsepsi pemberdayaan, penilaian dan pelaporan KKN, teknologi tepat guna, teknologi informasi pedesaan, metode pembelajaran pendidikan formal/in formal, pemerintahan dan budaya pedesaan madura, manajemen UMKM, pengelolaan wisata syariah.

3. Survey dan Observasi Lokasi KKN : Fokus dari kegiatan ini adalah observasi mendalam dalam rangka mengetahui potensi/kekuatan, kelemahan, peluang dan ancaman yang dihadapi oleh warga Desa Nagasareh, Pelanggaran Barat dan Masaran. Kegiatan ini didampingi oleh DPL dengan tujuan agar dapat memberikan arahan kepada mahasiswa agar mampu mengidentifikasi kondisi dengan dengan lebih baik.. Dari kegiatan ini diperoleh hasil sebagai berikut:

terbentuk kesepahaman antara mahasiswa KKN/DPL dengan perangkat desa terkait dengan fokus kegiatan yang akan dilakukan terkait dengan pengembangan kawasan desa wisata syariah dan b) pemetaan daftar kebutuhan desa terutama yang terkait dengan kegiatan pemberdayaan dan peningkatan keterampilan masyarakat.

4. Penyusunan Program Kerja KKN-PPM : Penyusunan program kerja ini dilakukan oleh mahasiswa KKN dengan arahan dari DPL dan tim Panitia KKN-PPM. Program kerja yang disusun harus mengacu pada tema kegiatan KKN-PPM yaitu pemberdayaan masyarakat tergusur akibat pembangunan Bendungan Nipah-Sampang melalui pengembangan kawasan desa wisata syariah.

5. Pemaparan Usulan Program KKN-PPM : Kegiatan ini dilakukan untuk mengarahkan program kerja mahasiswa agar sesuai dengan target dan sasaran yang ditetapkan melalui program KKN-PPM ini. Mahasiswa diwajibkan mempresentasikan usulan program yang telah disusun dihadapkan tim Panelis yang dibentuk oleh LPPM. Selanjutnya tim panelis memberikan evaluasi, koreksi dan saran. Hasil evaluasi dari tim panelis terhadap usulan program mahasiswa KKN-PPM adalah a) Desa Masaran: programnya terlalu banyak dan kurang fokus sehingga disarankan untuk memfokuskan pada beberapa kegiatan saja. b) Desa Nagasareh: untuk kegiatan pembuatan mocaf hendaknya diperhatikan kesesuaian dan kecukupan waktu KKN-PPM. c) Desa Pelanggaran barat: Sudah cukup baik hanya ada rencana output kegiatan yang harus dikurangi. Setelah kegiatan pemaparan program, mahasiswa KKN-PPM harus memperbaiki usulan programnya dan selanjutnya diserahkan kembali ke tim panelis untuk diverifikasi.

6. Pelaksanaan Kegiatan KKN-PPM : Mahasiswa berangkat ke desa dengan didampingi oleh DPL masing-masing. Rombongan mahasiswa KKN menuju ke Kantor Kecamatan Banyuates untuk diterima oleh Muspika sekaligus mendapatkan pengarahan dan pemantapan orientasi lapang. Pada kesempatan tersebut DPL mengantar mahasiswa sampai ke Posko KKN-PPM di desa dan menitipkan mahasiswa ke kepala desa masing-masing. Kegiatan yang telah dilaksanakan adalah dapat dibagi menjadi tiga yaitu a) kegiatan yang terkait langsung dengan program utama, b) kegiatan suplemen yang masuk dalam program pendukung. 

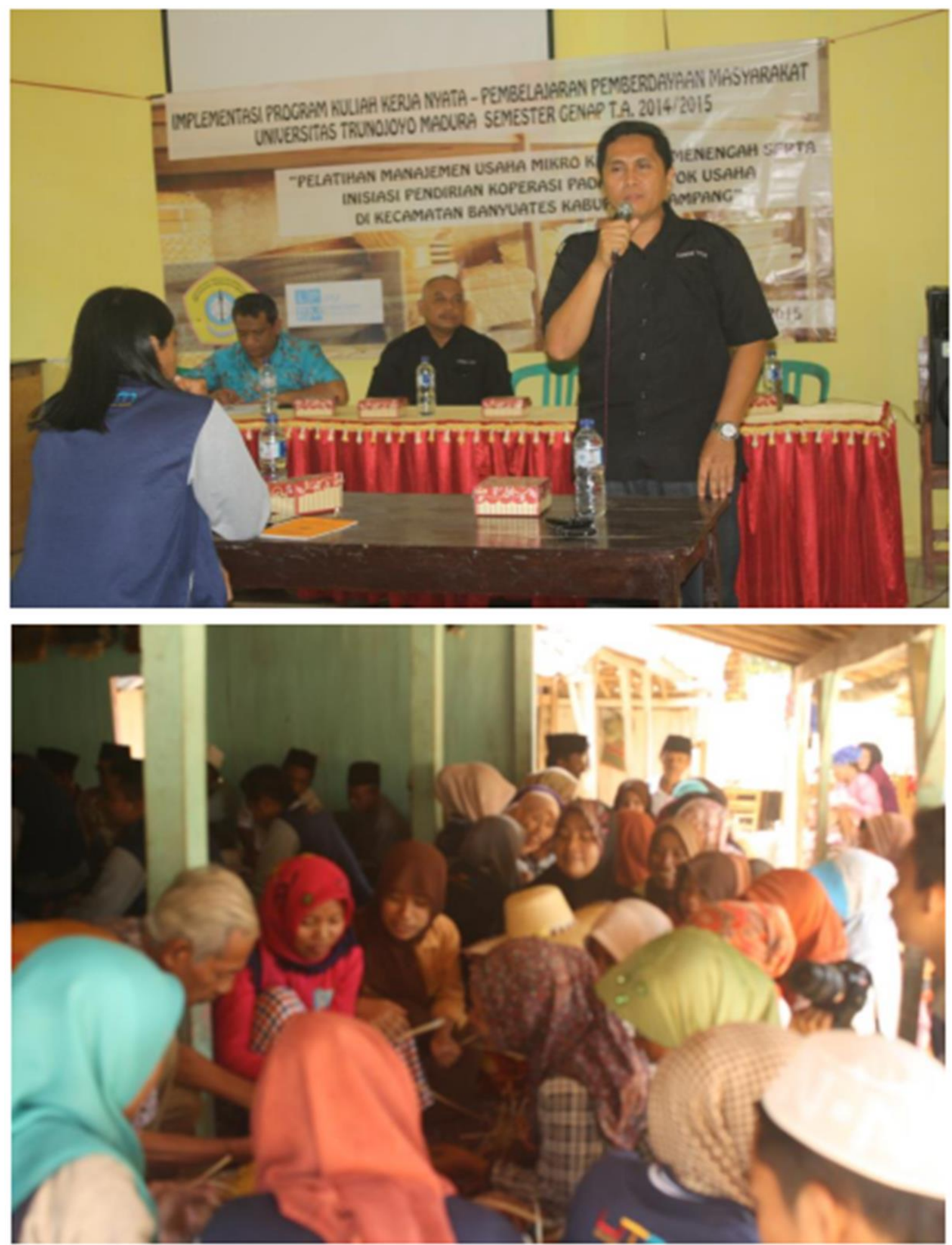

Gambar 1. Pemberian Materi Pemberdayaan Masyarakat

7. Monitoring dan Evaluasi oleh DPL : Dosen pembimbing lapang melaksanakan monitoring dan evaluasi pelaksaaan kegiatan mahasiswa KKN-PPM setiap minggu. DPL memonitor pelaksanaan program kerja mahasiswa, mengevaluasi ketercapaian jadwa kegiatan serta efektifitas dari kegiatan yang dilakukan.
Setiap DPL harus terlibat dalam kegiatan mahasiswa minimal satu kali. DPL juga memeriksa kelengkapan administrative mahasiswa seperti log book, laporan kegiatan dll. Hasil monitoring dan evaluasi menunjukkan bahwa semua kegiatan mahasiswa telah berjalan dengan baik meskipun ada beberapa kegiatan yang kurang 
efektif seperti pelatihan manajemen usaha dan pembukaan.

8. Monitoring dan Evaluasi Program : Tim panitia dari LPPM juga melaksanakan monitoring dan evaluasi terhadap semua kelompok KKN. Setiap kelompok di Monev dua kali selama pelaksanaan KKN. Terdapat beberapa aspek yang dimonitoring yaitu: a. Kesesuaian usulan dan realisasi program, b. Partisipasi masing-masing anggota, c. Kelengkapan administratif (rekap identifikasi masalah, log book, satuan acara kegiatan, buku tamu, daftar hadir kegiatan dan lainlain), d. Laporan kegiatan dan lainnya (web desa, profil desa, buku desa). Hasil dari monitoring pertama menunjukkan bahwa secara administratif semua kelengkapan sudah terpenuhi namun belum terdokumentasi dengan baik. Namun pada monev kedua permasalahan ini sudah teratasi.

9. Pameran dan Ujian Akhir: Penutupan ditandai dengan diadakannya pameran produk unggulan desa KKN yang dilaksanakan di Gedung Graha utama. Pada kegiatan tersebut semua desa diberi satu meja dan diminta untuk memamerkan produk yang dihasilkan oleh mahasiswa dan masyarakat. LPPM juga memberikan penilaian terhadap pameran KKN tersebut dan juga merupakan bagian dari komponen penilaian KKN. Hasil dari pameran KKN ini menunjukkan bahwa mahasiswa KKN-PPM mampu menghasilkan produk unggulan KKN yang baik dan berpotensi untuk dikembangkan. Hal ini terbukti dengan dua dari tiga kelompok KKN-PPM yang bertema "Pengembangan Kawasan Desa Wisata Syariah" mampu keluar sebagai juara.

\section{KESIMPULAN}

Hasil dari kegiatan KKN-PPM ini adalah terbentuknya dua kelompok usaha kerajinan bambu di Desa Nsagasareh dan Desa Pelanggaran Barat sebagai kelanjutan dari Kelompok Posdaya yang telah dibentuk pada KKN periode sebelumnya, Kedua kelompok usaha tersebut telah mampu membuat 10 varian produk kerajinan bambu sebagai hasil pelatihan. Kemampuan masyarakat dalam manajemen usaha dan pembukaan sederhana meningkat. Telah tumbuh pemahaman masyarakat akan adanya potensi ekonomi melalui pengembangan kawasan desa wisata di Bendungan Nipah. Untuk keberlanjutan program ini maka diperlukan dukungan dari pemerintah untuk mendorong berkembangnya kelompok usahakerajinan bambu melalui penyediaan bantuan teknis sehingga usaha tersebut dapat segera berkembang. Selain itu diperlukan juga menjaga hubungan baik dan networking dengan kelompok kerajinan Gunung Kawi yang telah bersedia menerima produk dari daerah KKN-PPM dengan syarat kuantitas dan kualitas serta kontinitas produk terpenuhi.

\section{DAFTAR PUSTAKA}

Badan Pusat Statistik. 2014. Kecamatan Banyuates dalam Angka. Sampang.

Badan Pemberdayaan Masyarakat Kabupaten Sampang. 2014. Profil Desa Masaran. Sampang.

Badan Pemberdayaan Masyarakat Kabupaten Sampang.2014. Profil Desa Nagasareh.

Badan Pemberdayaan Masyarakat Kabupaten Sampang. 2014. Profil Desa Pelanggaran Barat

Rangkuti, F. 2004. Business Plan: Teknik Membuat Perencanaan Bisnis dan Analisis Bisnis. Gramedia Pustaka Utama. Jakarta 
Sunyigono, A.K Ekawati, R \& Hayati, M Pemberdayaan Masyarakat Tergusur 47 